\title{
Glycosylated fibronectin positivity in the spectrum of hypertensive disorders of pregnancy in relation to the severity and adverse outcomes
}

\author{
Pratibha Devabhaktuni $^{1 *}$, Malati Ponnuru1, Chaithra L. Devang1, P. V. Rao
}

\author{
${ }^{1}$ Department of Obstetrics and Gynaecology, Modern Government Maternity Hospital, Osmania Medical College, \\ Hyderabad, Telangana, India \\ ${ }^{2}$ Diabetomics, Hyderabad, Telangana, India
}

Received: 28 January 2022

Revised: 10 February 2022

Accepted: 11 February 2022

\author{
*Correspondence: \\ Dr. Pratibha Devabhaktuni, \\ E-mail:dpdnk@yahoo.com
}

Copyright: () the author(s), publisher and licensee Medip Academy. This is an open-access article distributed under the terms of the Creative Commons Attribution Non-Commercial License, which permits unrestricted non-commercial use, distribution, and reproduction in any medium, provided the original work is properly cited.

\section{ABSTRACT}

Background: The aim of the study was to estimate the levels of glycosylated fibronectin (GlyFn) in preeclampsia (PE), and hypertensive disorders of pregnancy (HDP) and to correlate with the severity of the disease, adverse outcomes and complications. The study included 77 cases of HDP that were managed in the Institute of Obstetrics and Gynaecology, Modern Government Maternity Hospital (MGMH), Osmania Medical College, Hyderabad.

Methods: This study was a prospective non-interventional analytical investigative study. To ascertain the performance of this biomarker, GlyFn, we evaluated the LumellaTM GlyFn POC test.

Results: GlyFn positivity percentage was found to be highest in eclampsia (78.57\%), next in PE with severe features $74.07 \%$, in HELLP syndrome and gestational hypertension (HTN) (71.42\%). In PE without severe features (66.66\%) and in chronic HTN with PE superimposed (55.55\%). Maternal complications include: abruption 5 (6.57\%), thrombocytopenia 3 (3.94\%), acute kidney injury (AKI) 3 (3.94\%), post-partum hemorrhage (PPH) 3 (3.94\%), and ascites $3(3.94 \%)$. Perinatal outcome in 77 cases include: fetal growth restriction in $18(23.37 \%)$ and total perinatal mortality was $14(18.18 \%)$.

Conclusions: GlyFn positivity was found to be highest in eclampsia and the severe forms of PE. The positivity declined in the less severe disease. The birth weight in the severe forms of PE group was significantly lower $(p<0.0006)$. The differences in the birth weight among the GlyFn positive and normal groups was not significant for this population size $(\mathrm{p}=0.38)$.

Keywords: Preeclampsia, Eclampsia, HELLP, Glycosylated fibronectin, Hypertensive disorders of pregnancy

\section{INTRODUCTION}

Preeclampsia (PE) is a condition characterized by hypertension (HTN) in pregnancy with multi organ involvement that is unique to pregnancy and occurs in up to $7 \%$ of all pregnancies. ${ }^{1}$ Hypertensive disorders, including PE, are the second leading cause of maternal mortality worldwide, responsible for $10-25 \%$ of all maternal deaths. ${ }^{2}$ Even in the high-income countries, $16 \%$ of maternal deaths can be attributed to hypertensive disorders of pregnancy (HDP)., ${ }^{2,3}$
The incidence of eclampsia in India was reported to range between 0.179 to $5 \%$, the average being $1.5 \%$ during the period from 1976 to $2015 .{ }^{4}$ Whereas maternal mortality was observed to show a declining curve, the perinatal mortality continued to remain high, as in 1984 it was $45 \%$ and in 2010 it ranged between $24.5-48 \%$. $^{4}$

The maternal mortality of $2.55 \%$ in the study of 666 cases of eclampsia and imminent eclampsia was less than that reported in collaborative eclampsia trial $3.8 \%$ and $2.6 \% .^{5}$ 
Gestational HTN occurs when HTN without proteinuria or severe features develops after 20 weeks of gestation and blood pressure levels return to normal in the postpartum period. $^{6}$

Gestational HTN is associated with adverse pregnancy outcomes and may not represent a separate entity from PE. ${ }^{7,8}$ Up to $50 \%$ of women with gestational HTN will eventually develop proteinuria or other end-organ dysfunction consistent with the diagnosis of PE, and this progression is more likely when the HTN is diagnosed before 32 weeks of gestation. ${ }^{9,10}$

In proteinuria, 666 cases of eclampsia and imminent eclampsia was reported from the same institute, there was nil proteinuria in $17.69 \%$ of the cases, and 1 plus proteinuria in $28.02 \%$ of our cases, which proved that proteinuria need not be present to diagnose eclampsia and PE. $^{5}$

Proteinuria in PE is a manifestation of renal involvement that results from glomerulo endothelial injury leading to altered permeability to proteins and abnormal tubular handling of filtered proteins.

Though categorized under different groups, they could represent, in the chronology of events, one continuous spectrum of the same underlying pathologic process.

Gestational HTN cases included in this group are: those with new onset HTN in pregnancy with less than 2 plus proteinuria. When they develop 2 plus proteinuria or any features of end organ damage, they would be classified as PE with or without severe features.

Hence the so called gestational HTN would be, or could be the initial manifestation of the disease entity of PE in progression.

A number of circulating factors have been shown to be associated with PE, including soluble endoglin, placental growth factor (PIGF), soluble fms-like tyrosine kinase-1 (sFlt-1), vascular endothelial growth factor (VEGF), pregnancy-associated plasma protein A-2 (PAPPA2), GlyFn, vasopressin, and copeptin. ${ }^{11-15}$

The majority of the Fn present in serum or plasma is termed plasma Fn (pFn), which is produced and secreted in a soluble form by hepatocytes, while so-called cellular Fn (cFn) is produced by numerous cell types, including fibroblasts, endothelial cells, and smooth muscle cells.

The study by Rasanen et al demonstrates that the maternal serum proteome in clinical PE differs from that in normotensive pregnancies. ${ }^{16}$ Cluster analysis of more than 3,400 serum proteins identified distinct clusters of maternal serum proteins up-regulated in PE. ${ }^{16}$

Increased GlyFn levels were significantly associated with gestational age at delivery $(\mathrm{p}<0.01)$, blood pressure
$\left(\mathrm{P}^{1} / 4=0.04\right)$, and small-for gestational-age neonates. Rasanen et al concluded that GlyFn is a robust biomarker for monitoring of PE in both a standard and POC format, which supports its utility in diverse settings. ${ }^{17}$

Huhn et al report that their results demonstrate that multiple biomarkers exhibit high performance in prediction of PE in the short term, and that GlyFn is adaptable to a POC format. ${ }^{18}$

Huhn et al concur with the opinion of other researchers that biomarkers should be incorporated into the definition of placental PE. ${ }^{19-23}$ The development of the GlyFn POC test may enable rapid prediction of $\mathrm{PE}$, an inexpensive test that can be performed even in remote rural India. Simplicity in performing the test would definitely find wider acceptance by the population, as well as the medical fraternity.

In a retrospective case control study done by Reddy from Rainbow Hospitals, Hyderabad, patients with GlyFn levels more than $350 \mu \mathrm{g} / \mathrm{ml}$ were included in the study group. ${ }^{24}$ They have reported that maternal and fetal morbidity leading to delivery within 10 days of testing ( $p$ value $=0.0035,95 \% \mathrm{CI} 4.05$ to 19.13 ) and worsening of Dopplers ( $\mathrm{p}$ value $=0.0031$ ) is significantly high in study group. $^{24}$

The LumellaTM GlyFn POC test, (GlyFn point-of-care test for diagnosis of $\mathrm{PE}$ ) has been validated in a low/middle-income country setting for PE diagnosis. ${ }^{25} \mathrm{It}$ has been concluded in the study that this may be a useful diagnostic tool for early identification, and appropriate early institution of treatment, so as to reduce adverse maternal and fetal outcomes. ${ }^{25}$

Alternative forms of fibronectin have been demonstrated to play a role in acute inflammation and ischemia, vascular remodeling and placental insufficiency and oxygen levels may contribute to altered glycosylation of glycoproteins like fibronectin. Two stages are described in the pathogenesis of PE. In the first stage, trophoblastic invasion early in pregnancy, is thought to be inadequate and fails to remodel spiral arteries leading to reduced placental perfusion. The inadequate trophoblastic invasion could be due to immune-mediated interactions and reduced local oxygen supply in the second stage, clinical manifestations of PE become apparent. ${ }^{16}$

The proteomic profile in preclinical PE, is considered to be different and distinct from that in clinical PE. ${ }^{16}$ Fibronectin is involved in tissue repair. In clinical PE both total and cellular fibronectin levels have been reported to be elevated. $^{26}$

In this study the percentage of positivity for GlyFn was estimated in the diagnosed cases of gestational HTN, in chronic HTN along with PE superimposed, in PE without severe features, PE with severe features, eclampsia and HELLP syndrome. Though categorized under different groups, they could represent, in the chronology of events, 
one continuous spectrum of the same underlying pathologic process.

A literature search reveals that plasma fibronectin has long been associated with preeclampsia, first suggested in 1984 as a biomarker for endothelial damage, and subsequently reported to be an important mediator in inflammation, ischemia, and vascular remodeling. ${ }^{27}$

The objectives of the study were: to determine the levels of GlyFn in women with PE and HDP; and to evaluate the association between positive GlyFn levels and severity of PE and HDP. The adverse pregnancy outcomes, including complications have been assessed.

\section{METHODS}

\section{Study design}

Prospective non-interventional analytical investigative study was conducted.

\section{Study place}

The study was conducted among the 77 cases of HDP, that were managed in the Institute of Obstetrics and Gynaecology, Modern Government Maternity Hospital (MGMH)/Osmania Medical College, Hyderabad.The study was conducted during the years 2019-2020.

\section{Primary outcomes}

It includes: association of positive GlyFn levels in PE and HDP, and to assess the adverse pregnancy outcomes, including complications.

\section{Study subjects}

It includes study subjects admitted to MGMH, Petlaburz for PE management and cases of HDP; study subjects-PE new-onset HTN with systolic blood pressure $\geq 140 \mathrm{~mm} \mathrm{Hg}$ and/or diastolic blood pressure $\geq 90 \mathrm{~mm} \mathrm{Hg}$ measured on two occasions at least 6 hours apart at $>20$ weeks of gestation with proteinuria $[\geq 2$ on random urine protein dipstick]; and diagnosed cases of PE and HDP, admitted for management.

To ascertain the performance of this biomarker, glycosylated fibronectin (GlyFn), we evaluated the LumellaTM GlyFn POC test (DiabetOmics, Inc., Beaverton, OR, USA), which uses a fingerstick blood sample and an inexpensive hand-held reader, to confirm PE cases. Test strips were configured. Enrolment criteria were subjects with GH or PE were enrolled at the time that HTN was diagnosed. We also included PE with severe features, PE without severe features, eclampsia, HELLP syndrome and chronic HTN with superimposed PE cases were tested for GlyFn.
Point-of-care test (LumellaTM test system) serum samples were analysed for GlyFn using a second generation LumellaTM PE test (DiabetOmics, Inc.) according to the manufacturer's instructions. Test strips were configured with monoclonal antibodies against GlyFn labeled with gold particles for quantification using a hand-held LumellaTM reader system (Figure 1).

The procedure described is, $5 \mu$ of serum was diluted 1:350 in running buffer and $120 \mu \mathrm{l}$ of diluted serum added to the test strip and inserted into the reader. The GlyFn concentration is displayed on the reader at the end of 10 minutes.

Patients with GlyFn levels more than $350 \mu \mathrm{g} / \mathrm{ml}$ were considered positive. Values less than $250 \mu \mathrm{g} / \mathrm{ml}$ were considered negative. Values between $250 \mu \mathrm{g} / \mathrm{ml}$ and 350 $\mu \mathrm{g} / \mathrm{ml}$ were considered abnormal, where a repeat test was advised. In this study we have included the abnormal test result, in three women, also as a positive result. Management of the cases was as per the protocol followed in the hospital for PE, eclampsia and HELLP syndrome. The results of the test were not considered in making a decision regarding the management adopted.

\section{Ethical approval}

The competent ethics committee, Osmania Medical College, approved the study protocol, and written informed consent was obtained from all participants.

\section{Statistical analysis}

$\mathrm{P}$ values were calculated using t test (2-tailed, variance not equal) on Google sheets.

\section{RESULTS}

Among the 77 cases of HDP, that were managed in the institute, there were gestational HTN, N=14, PE without severe features $\mathrm{N}=6, \mathrm{PE}$ with severe features $\mathrm{N}=27$, chronic HTN with PE superimposed $\mathrm{N}=9$, eclampsia $\mathrm{N}=14$, and HELLP syndrome $\mathrm{N}=7$. In cases diagnosed to have developed HELLP syndrome, six had features of severe preeclampsia and one was a case of eclampsia with HELLP syndrome (Table 1).

A total of 77 cases with various types of HDP were managed at the Institute of Obstetrics and Gynaecology, at MGMH/Osmania Medical College, Hyderabad, during the years 2019 and 2020.

\section{GlyFn positivity percentage}

In this study the percentage of positivity was found to be highest, in eclampsia, $78.57 \%$, next in PE with severe features $74.07 \%$. In descending order the GlyFn positivity was found to be in HELLP syndrome and gestational HTN, $71.42 \%$. In PE without severe features, the GlyFn 
positivity was $66.66 \%$ and in chronic HTN with PE superimposed, a positivity rate of $55.55 \%$ (Table 1).

\section{Birth weight}

In the six groups of PE, including gestational HTN, is shown in Table 2. It is a significant point to note that in cases of eclampsia, HELLP syndrome and PE with severe features, there is a shift to the weights less than $2.5 \mathrm{kgs}$ (Table 3). PE with severe features, eclampsia and HELLP, $\mathrm{N}=48$, and in gestational HTN, PE with less severe features and chronic HTN with superimposed PE, there is a shift to weights being more than $2.5 \mathrm{kgs}$ (Table 4).

A birth weight of $2.6 \mathrm{kgs}$ and above was recorded in $25.61 \%$ of the cases of HDP. While a birth weight of 2.5 $\mathrm{kgs}$ and below was recorded in $74.39 \%$ of the cases of HDP. It is noteworthy that in HDP $74.39 \%$ of the cases were small for gestational age (SGA) newborns (Tables 5 and 6).

\section{Delivery}

Delivery was by lower segment caesarean section (LSCS) in $45(58.44 \%)$ and vaginal delivery in $32(41.55 \%)$. Labour was induced in $22 / 77=41.55 \%$ (Table 7).

\section{Perinatal outcome}

In 77 cases, fetal growth restriction in $18(23.37 \%)$, neonatal intensive care unit (NICU) admissions 34 (44.73\%), intrauterine fetal death (IUFD) 9 (11.84\%), NND $4(5.26 \%)$ and SB $1(1.31 \%)$ (Table 7$)$.

Interval from the time of diagnosis of HTN to delivery at the institute is shown in Table 8.

This institute being a tertiary referral centre in the public sector, the patients are offered free medical service, hence the patients are referred when complications develop. The number of days the pregnancy is continued or immediate delivery is planned would be based on the maternal and fetal condition. The number of day's expectant management given to each patient prior to admission would not be possible to assess. The data provided in the table gives information regarding management instituted at the institute.

\section{The associated maternal conditions and complications}

In the 77 cases were: severe anemia in 11/77 (14.28\%), hypothyroidism in $9(11.68 \%)$, gestational diabetes mellitus (GDM) and overt DM in 8 (10.39\%), multiple gestation in $5(6.49 \%)$, other conditions, abruption in 5 (6.57\%), thrombocytopenia in $3(3.94 \%)$, AKI in 3 $(3.94 \%)$, PPH in $3(3.94 \%)$, ascitis in $3(3.94 \%)$, fetal growth restriction in $18(23.37 \%)$, acute pancreatitis 1 , retinopathy, temporary loss of vision 1 , herpes zoster 1 , and Rh negative 1 (Table 9).

\section{Maternal complications in different groups}

In HELLP syndrome, the following complications were recorded, severe anaemia 5, AKI 3, thrombocytopenia 3, placental abruption 2, PPH 2, and acute pancreatitis 1 .

\section{Associated maternal conditions}

In gestational HTN, chronic liver disease and portal HTN 1 , grade 3 diastolic dysfunction 1 . These conditions could influence the maternal and fetal complications.

In $\mathrm{PE}$ with severe features the following complications were recorded, Rh negative 1 , abruption 1, oligoamnios 6 , abnormal Doppler blood flow 4, ascites 2, and Herpes zoster 1 .

\section{Fetal and neonatal complications}

Fetal growth restriction (FGR) was highest in the group PE with severe features, $15 / 27(55.55 \%)$, with IUD in $3 / 27$ $(11.11 \%)$.

In the group of eclampsia, FGR occurred in 3/14 (21.42\%) and still birth 1, IUD 1, and NND 2, were recorded. with a perinatal mortality of $4 / 14(28.57 \%)$.

There were 2 cases of IUD in gestational HTN, 2/14 (14.28\%), and in the group of chronic HTN 2/9 (22.22\%).

\section{Eclampsia (14)}

Eclampsia occurred antepartum in 4 , intrapartum in 3 , imminent in 5 , and postpartum in 2 cases.

In one case of imminent eclampsia, a complication of HELLP developed, included under HELLP group.

In HELLP syndrome multiple units of blood products were needed in 6 cases.

\section{Statistical analysis of the data}

The severe disease included PE with severe features $\mathrm{N}=27$, eclampsia $\mathrm{N}=14$, HELLP syndrome $\mathrm{N}=7$, total $\mathrm{n}=48$ cases (52 neonates) with 4 sets of twins in this category. The GlyFn positive, $n=36$, GlyFn normal, $n=12$, out of total $\mathrm{n}=48$.

The less severe disease included, PE without severe features $n=6$, gestational HTN $n=14$, chronic HTN with PE superimposed $n=9$, total $n=29$ (30 neonates) with one set of twins in this category. The GlyFn positive, $n=19$, GlyFn normal, $n=10$, out of total $n=29$.

No apparent difference in birth weights was observed in GlyFn positive and GlyFn normal groups in the category of severe hypertensive cases, 1.92 and $1.94 \mathrm{~kg}$ 
respectively, $\mathrm{n}=48$ cases ( 52 neonates) with 4 sets of twins in this category.

Similarly a small difference in birth weights in GlyFn positive and GlyFn normal groups in the category of less severe PE and hypertensive cases, 2.53 and $2.67 \mathrm{~kg}$ respectively, $n=29$ cases (30 neonates) with one set of twins in this category.

When GlyFn positivity was $75 \%$ in the severe disease of $\mathrm{PE}$, the birth weight mean was $1.93 \mathrm{~kg}(\mathrm{n}=48)$. When GlyFn positivity was $65.51 \%$ in the less severe disease of $\mathrm{PE}$ and HDP, the birth weight mean was $2.58 \mathrm{~kg}(\mathrm{n}=29)$.
The mean birth weight in the severe forms of preeclampsia group was $1.93( \pm 0.62)$ kilograms, while the mean birth weight in the less severe forms of PE and HDP group was $2.58( \pm 0.83)$. The birth weight in the severe forms of preeclampsia group was significantly lower $(\mathrm{p}<0.0006)$.

When the population was divided into two groups based on GlyFn, the positive group had a mean birth weight of $2.13( \pm 0.82)$, whereas the normal group had a mean birth weight of $2.28( \pm 0.64)$. The differences in the birth weight among these groups was not significant for this population size $(\mathrm{p}=0.38)$. $P$ values were calculated using $t$ test $(2-$ tailed, variance not equal) on Google sheets.

Table 1: GlyFn positivity in the spectrum of hypertensive disorders.

\begin{tabular}{|llllll|}
\hline Hypertensive disorders & \multicolumn{2}{c}{ GlyFn +ve } & GlyFn normal \\
\hline PE without severe symptoms & $\mathbf{N}$ & $\mathbf{n}$ & $\mathbf{\%}$ & $\mathbf{n}$ & \% \\
\hline Gestational hypertension & 6 & 4 & 66.67 & 2 & 33.33 \\
\hline Chronic hypertension+PE & 14 & 10 & 71.43 & 4 & 28.57 \\
\hline PE with severe symptoms & 9 & 5 & 55.56 & 4 & 44.44 \\
\hline Eclampsia & 27 & 20 & 74.07 & 7 & 25.93 \\
\hline HELLP & 14 & 11 & 78.57 & 3 & 21.43 \\
\hline
\end{tabular}

Table 2: GlyFn positivity in the spectrum of HDP in relation to the birth weight and days pregnancy continued after test.

\begin{tabular}{|llllllll|}
\hline \multirow{2}{*}{ Spectrum of HDP } & \multicolumn{2}{l}{ GlyFn +ve } & & & \multicolumn{2}{l|}{ GlyFn normal } \\
& $\mathbf{N}$ & $\mathbf{n}$ & Mean \pm SD & Range & n & Mean \pm SD & Range \\
\hline Birth weight $(\mathbf{k g})$ & & & & & & & \\
\hline PE without severe symptoms & 6 & 4 & $2.71 \pm 0.48$ & $2.14-3$ & 2 & $3.05 \pm 0.21$ & $2.9-3$ \\
\hline Gestational hypertension & 14 & 11 & $2.66 \pm 0.82$ & $1.4-4$ & 4 & $2.50 \pm 0.82$ & $1.5-4$ \\
\hline Chronic hypertension+PE & 9 & 5 & $2.08 \pm 1.46$ & $0.26-4$ & 4 & $2.65 \pm 0.44$ & $2.1-3$ \\
\hline PE with severe symptoms & 27 & 22 & $2.14 \pm 0.54$ & $1.1-3$ & 7 & $1.73 \pm 0.51$ & $1.2-3$ \\
\hline Eclampsia & 14 & 12 & $1.66 \pm 0.71$ & $0.58-3$ & 3 & $2.23 \pm 0.12$ & $2.1-2$ \\
\hline HELLP & 7 & 5 & $1.60 \pm 0.79$ & $1-3$ & 2 & $2.55 \pm 0.07$ & $2.5-3$ \\
\hline Pregnancy days, after test & & & & & & & \\
\hline PE without severe symptoms & 6 & 4 & $19.00 \pm 24.54$ & $2-55$ & 2 & $3.00 \pm 1.41$ & $2-4$ \\
\hline Gestational hypertension & 14 & 10 & $19.60 \pm 19.92$ & $0-50$ & 4 & $41.00 \pm 24.94$ & $11-63$ \\
\hline Chronic hypertension+PE & 9 & 5 & $42.80 \pm 70.16$ & $0-\# \# \#$ & 4 & $47.00 \pm 40.49$ & $4-97$ \\
\hline PE with severe symptoms & 27 & 20 & $12.75 \pm 18.70$ & $0-69$ & 7 & $2.14 \pm 3.93$ & $0-10$ \\
\hline Eclampsia & 14 & 11 & $3.18 \pm 6.26$ & $0-21$ & 3 & $1.33 \pm 1.53$ & $0-3$ \\
\hline HELLP & 7 & 5 & $1.60 \pm 3.58$ & $0-8$ & 2 & $0 \pm 0$ & 0 \\
\hline
\end{tabular}

GlyFn: Glycosylated fibronectin, +ve $>350 \mu \mathrm{g} / \mathrm{ml}$, normal $<250 \mu \mathrm{g} / \mathrm{ml}$

Table 3: Preeclampsia, eclampsia and HELLP, with severe features $N=48$.

\begin{tabular}{|llllll|}
\hline Gycosylated fibronectin positive & & \multicolumn{3}{l|}{ Gycosylated fibronectin normal } \\
\hline S. no. & Birth weight in $\mathbf{k g}$ & Number of days & S. no. & Birth weight in $\mathbf{k g}$ & Number of days \\
\hline 1 & 2.5 & 35 & 1 & 2.5 & 0 \\
\hline 2 & 1.75 & 3 & 2 & 1.9 & 5 \\
\hline 3 & 3.0 & 16 & 3 & 1.3 & 0 \\
\hline 4 & 10 & 11 & 4 & 1.2 & 10 \\
\hline 5 & 1.8 & 0 & 5 & 1.9 & 0 \\
\hline 6 & 3.0 & 3 & 6 & 1.2 and 1.4 & 0 \\
\hline 7 & 1.6 & & 7 & 2.1 & 0 \\
\hline
\end{tabular}

Continued. 


\begin{tabular}{|c|c|c|c|c|c|}
\hline \multicolumn{3}{|c|}{ Gycosylated fibronectin positive } & \multicolumn{3}{|c|}{ Gycosylated fibronectin normal } \\
\hline 8 & 2.0 & 2 & - & - & - \\
\hline 9 & 2.5 & 3 & - & - & - \\
\hline 10 & 1.5 & 0 & - & - & - \\
\hline 11 & 2.6 & 0 & - & - & - \\
\hline 12 & 2.5 & 28 & - & - & - \\
\hline 13 & 1.3 & 1 & - & - & - \\
\hline 14 & 2.5 and 2.5 & 39 & - & - & - \\
\hline 15 & 2.5 & 0 & - & - & - \\
\hline 16 & 2.1 & 0 & - & - & - \\
\hline 17 & 2.2 & 69 & - & - & - \\
\hline 18 & 2.6 & 2 & - & - & - \\
\hline 19 & 2.1 and 2.2 & 33 & - & - & - \\
\hline 20 & 1.1 & 0 & - & - & - \\
\hline Average & 2.14 & - & - & 1.68 & - \\
\hline \multicolumn{6}{|c|}{ Eclampsia $N=14$} \\
\hline 1 & 2.0 & 21 & 1 & 2.1 & 3 \\
\hline 2 & 1.4 & 0 & 2 & 2.3 & 1 \\
\hline 3 & 1.3 & 0 & 3 & 2.3 & 0 \\
\hline 4 & 0.9 & 2 & - & - & - \\
\hline 5 & 2.4 & 2 & - & - & - \\
\hline 6 & 0.670 and 0.580 & 2 & - & - & - \\
\hline 7 & 2.0 & 0 & - & - & - \\
\hline 8 & 2.5 & 0 & - & - & - \\
\hline 9 & 1.4 & 7 & - & - & - \\
\hline 10 & 2.25 & 1 & - & - & - \\
\hline 11 & 2.5 & 0 & - & - & - \\
\hline Average & 1.6583 & - & - & 2.2333 & - \\
\hline \multicolumn{6}{|c|}{ HELLP N=7 } \\
\hline 1 & 1.2 & 8 & 1 & 2.6 & 0 \\
\hline 2 & 1.0 & 0 & 2 & 2.5 & 0 \\
\hline 3 & 2.8 & 0 & - & - & - \\
\hline 4 & 2.0 & 0 & - & - & - \\
\hline 5 & 1.0 & 0 & - & - & - \\
\hline Average & 1.6 & - & - & 2.55 & - \\
\hline
\end{tabular}

Table 4: Preeclampsia and HDP with less severe features $\mathbf{N}=29$.

\begin{tabular}{|c|c|c|c|c|c|}
\hline \multicolumn{3}{|c|}{ Gycosylated fibronectin positive } & \multicolumn{3}{|c|}{ Gycosylated fibronectin normal } \\
\hline S. no. & Birth weight in $\mathrm{kg}$ & Number of days & S. no. & Birth weight in kg & Number of days \\
\hline \multicolumn{6}{|c|}{ Preeclampsia with less severe features $\mathrm{N}=6$} \\
\hline 1 & 3.2 & 14 & 1 & 3.2 & 2 \\
\hline 2 & 3.0 & 2 & 2 & 2.9 & 4 \\
\hline 3 & 2.14 & 5 & - & - & - \\
\hline 4 & 2.5 & 55 & - & - & - \\
\hline Average & 2.71 & & & 3.05 & \\
\hline \multicolumn{6}{|c|}{ Gestational hypertension $\mathrm{N}=14$} \\
\hline 1 & 3.4 & 0 & 1 & 3.5 & 60 \\
\hline 2 & 2.3 & 32 & 2 & 1.5 & 30 \\
\hline 3 & 2.5 and 3.0 & 9 & 3 & 2.5 & 11 \\
\hline 4 & 2.9 & 6 & 4 & 2.5 & 63 \\
\hline 5 & 3.0 & 50 & - & - & - \\
\hline 6 & 2.1 & 1 & - & - & - \\
\hline 7 & 4.0 & 48 & - & - & - \\
\hline 8 & 1.4 & 37 & - & - & - \\
\hline
\end{tabular}




\begin{tabular}{|llllll|}
\hline Gycosylated fibronectin positive & \multicolumn{5}{l}{ Gycosylated fibronectin normal } \\
\hline 9 & 3.3 & 9 & - & - & - \\
\hline 10 & 1.4 & 4 & - & - & - \\
\hline Average & 2.6636 & - & - & 2.5 & - \\
\hline 1 & 0.260 & 0 & 1 & 3.0 & 60 \\
\hline 2 & 2.5 & 167 & 2 & 3.0 & 4 \\
\hline 3 & 3.3 & 14 & 3 & 2.1 & 27 \\
\hline 4 & 0.861 & 6 & 4 & 2.5 & \\
\hline 5 & 3.5 & 27 & & & 2.65 \\
\hline Average & 2.0842 & & & & \\
\hline
\end{tabular}

Table 5: Birth weight: in the six groups of PE, including gestational hypertension.

\begin{tabular}{|c|c|c|c|c|c|c|c|c|}
\hline $\begin{array}{l}\text { S. } \\
\text { no. }\end{array}$ & Group & $\begin{array}{l}\text { Number of } \\
\text { cases }=77\end{array}$ & $<1.0 \mathrm{~kg}$ & $\begin{array}{l}1.1-1.5 \\
\mathrm{~kg}\end{array}$ & $\begin{array}{l}1.6-2.0 \\
\mathrm{~kg}\end{array}$ & $\begin{array}{l}2.1-2.5 \\
\mathrm{~kg}\end{array}$ & $\begin{array}{l}2.6-3.0 \\
\mathrm{~kg}\end{array}$ & $\begin{array}{l}3.1-3.5 \\
\mathrm{~kg}\end{array}$ \\
\hline 1 & PE without severe features & 6 & & & & $\begin{array}{l}2.5 \\
2.1\end{array}$ & $\begin{array}{l}3.0 \\
2.9\end{array}$ & $\begin{array}{l}3.2 \\
3.2\end{array}$ \\
\hline 2 & PE with severe features & 27 & & $\begin{array}{l}1.5 \\
1.4 \\
1.3 \times 3 \\
1.2 \times 2 \\
1.1-\end{array}$ & $\begin{array}{l}2.0 \\
1.9 \times 2 \\
1.8 \\
1.7 \\
1.6\end{array}$ & $\begin{array}{l}2.5 \times 7 \\
2.2 \times 2 \\
2.1 \times 3\end{array}$ & $\begin{array}{l}3.0 \\
3.0 \\
2.6 \times 2\end{array}$ & \\
\hline 3 & Gestational HTN & 14 & & $\begin{array}{l}1.1 \\
1.4 \\
1.4\end{array}$ & $1.5-$ & $\begin{array}{l}2.1 \\
2.3 \\
2.5 \\
2.5 \\
2.5\end{array}$ & $\begin{array}{l}3.0 \\
3.0-2.9\end{array}$ & $\begin{array}{l}3.1 \\
3.3 \\
3.4 \\
3.5\end{array}$ \\
\hline 4 & $\begin{array}{l}\text { Chronic HTN + with PE } \\
\text { superimposed }\end{array}$ & 9 & $\begin{array}{l}260 \mathrm{gms} \\
861 \mathrm{gms}\end{array}$ & & & $\begin{array}{l}2.5 \times 2 \\
2.1\end{array}$ & $3.0 \times 2$ & $\begin{array}{l}3.3 \\
3.5\end{array}$ \\
\hline 5 & Eclampsia & 14 & $\begin{array}{l}670 \mathrm{gms} \\
580 \mathrm{gms} \\
\text { twins } \\
900 \mathrm{gms}\end{array}$ & $\begin{array}{l}1.3- \\
1.4 \\
1.4\end{array}$ & $\begin{array}{l}2.0 \\
2.0\end{array}$ & $\begin{array}{l}2.1 \\
2.2 \\
2.3 \\
2.3 \\
2.4 \\
2.5 \\
2.5\end{array}$ & & \\
\hline 6 & $\begin{array}{l}\text { HELLP syndrome } \\
\text { PE with severe } \\
\text { Features- } 6 \\
\text { Eclampsia- } 1\end{array}$ & 7 & $\begin{array}{l}1.0- \\
1.0-\end{array}$ & $1.2-$ & 2.0 & & $\begin{array}{l}2.6 \\
2.8\end{array}$ & \\
\hline 7 & Total twins 5 sets included & $\begin{array}{l}77 \text { cases } \\
82 \text { neonates }\end{array}$ & 7 & 15 & 10 & 29 & 13 & 8 \\
\hline 8 & $\%$ & & 8.537 & 18.293 & 12.195 & 35.366 & 15.854 & 9.756 \\
\hline
\end{tabular}

A birth weight of $2.6 \mathrm{~kg}$ and above was recorded in $25.61 \%$ of the cases of HDP. While a birth weight of $2.5 \mathrm{~kg}$ and below was recorded in $74.39 \%$ of the cases of HDP. It is noteworthy that in HDP $74.39 \%$ of the cases are small for gestational age, SGA newborns

Table 6: Average birth weight in Glyfn positive and Glyfn normal cases in the six groups.

\begin{tabular}{|lllllll|}
\hline $\begin{array}{l}\text { S. } \\
\text { no. }\end{array}$ & Group & $\begin{array}{l}\text { Number } \\
\text { cases=77 }\end{array}$ & $\begin{array}{l}\text { Glyfn } \\
\text { positive }\end{array}$ & $\begin{array}{l}\text { Average } \\
\text { birth weight in kg }\end{array}$ & $\begin{array}{l}\text { Glyfn } \\
\text { normal }\end{array}$ & $\begin{array}{l}\text { Average } \\
\text { birth weight in kg }\end{array}$ \\
\hline $\mathbf{1}$ & PE without severe features & 6 & 4 & 2.71 & 2 & 3.05 \\
\hline $\mathbf{2}$ & PE with severe features & 27 & 20 & 2.143182 & 7 & 1.6875 \\
\hline $\mathbf{3}$ & Gestational HTN & 14 & 10 & 2.6636 & 4 & 2.5 \\
$\mathbf{4}$ & $\begin{array}{l}\text { Chronic HTN + } \\
\text { with PE superimposed }\end{array}$ & 9 & 5 & 2.0842 & 4 & 2.65 \\
\hline $\mathbf{5}$ & Eclampsia & 14 & 11 & 1.6583 & 3 & 2.2333 \\
\hline $\mathbf{6}$ & HELLP syndrome & 7 & 5 & 1.6 & 2 & 2.55 \\
\hline
\end{tabular}

Continued. 


\begin{tabular}{|llllll|}
\hline $\begin{array}{l}\text { S. } \\
\text { no. }\end{array}$ & $\begin{array}{r}\text { Number } \\
\text { cases=77 }\end{array}$ & $\begin{array}{l}\text { Glyfin } \\
\text { positive }\end{array}$ & $\begin{array}{l}\text { Average } \\
\text { birth weight in kg }\end{array}$ & $\begin{array}{l}\text { Glyfin } \\
\text { normal }\end{array}$ & $\begin{array}{l}\text { Average } \\
\text { birth weight in kg }\end{array}$ \\
$\begin{array}{l}\text { Features- } 6 \\
\text { Eclampsia- } 1\end{array}$ & & & & \\
\hline $\mathbf{7}$ & Total & 77 & 55 & 22 \\
\hline $\mathbf{8}$ & $\%$ & & 71.42 & 28.57 \\
\hline
\end{tabular}

Table 7: Hypertensive disorders of pregnancy 77 cases-mode of delivery and perinatal outcome in different groups.

\begin{tabular}{|c|c|c|c|c|c|c|c|c|}
\hline \multirow[b]{2}{*}{ Group } & \multirow[b]{2}{*}{$\mathrm{N}=77$} & \multirow{2}{*}{$\begin{array}{l}\text { Labour } \\
\text { induced }\end{array}$} & \multirow{2}{*}{$\begin{array}{l}\text { Vaginal } \\
\text { delivery }\end{array}$} & \multirow[b]{2}{*}{ LSCS } & \multicolumn{4}{|c|}{ Perinatal outcome } \\
\hline & & & & & NICU & IUD & NND & $\begin{array}{l}\text { Still } \\
\text { birth }\end{array}$ \\
\hline 1 PE without severe features & 6 & 3 & 3 & 3 & 2 & & & \\
\hline 2 PE with severe features & 27 & 6 & 9 & 18 & 16 & 2 & & \\
\hline 3 Gestational HTN & 14 & & 6 & 8 & 4 & 1 & 1 & \\
\hline $\begin{array}{l}\text { Chronic HTN + } \\
\text { with PE superimposed }\end{array}$ & 9 & 1 & 4 & 5 & 3 & 2 & & \\
\hline 5 Eclampsia & 14 & 8 & 6 & 8 & 6 & 2 & 2 & 1 \\
\hline $\begin{array}{l}\text { HELLP syndrome } \\
\text { 6E with severe } \\
\text { Features- } 6 \\
\text { Eclampsia- } 1 \\
\end{array}$ & 7 & 4 & $\begin{array}{l}4 \text { vacuum } \\
\text { assisted } \\
2\end{array}$ & 3 & 3 & 2 & 1 & \\
\hline 7 Total $=77$ & 77 & 22 & 32 & 45 & NICU-34 & IUD-9 & NND-4 & SB-1 \\
\hline $8 \%$ & & 28.57 & 41.55 & 58.44 & 44.15 & 11.68 & 5.19 & 1.29 \\
\hline
\end{tabular}

Mode of delivery: vaginal delivery was recorded in 32/77 (41.55\%). A caesarean delivery was necessary in 45/77 (58.44\%) of HDP cases

Table 8: Diagnosis to delivery interval.

\begin{tabular}{|c|c|c|c|c|c|c|c|}
\hline $\begin{array}{l}\text { S. } \\
\text { no. }\end{array}$ & Group & $\begin{array}{l}\text { Number } \\
\text { cases }=77\end{array}$ & $0-1$ day & $<7$ days & $<14$ days & $<21$ days & $>28$ days \\
\hline 1 & PE without severe features & 6 & & $\begin{array}{l}2-2 \\
4-1 \\
5-1\end{array}$ & & $14-1$ & $55-1$ \\
\hline 2 & PE with severe features & 27 & $\begin{array}{l}0-11 \\
1-1\end{array}$ & $\begin{array}{l}2-2 \\
3-3 \\
5-1\end{array}$ & $\begin{array}{l}10-2 \\
11-1\end{array}$ & $16-1$ & $\begin{array}{l}28-1 \\
33-1 \\
35-1 \\
39-1 \\
69-1\end{array}$ \\
\hline 3 & Gestational HTN & 14 & $\begin{array}{l}0-1 \\
1-1\end{array}$ & $\begin{array}{l}4-1 \\
6-1\end{array}$ & $\begin{array}{l}9-2 \\
11-1\end{array}$ & & $\begin{array}{l}30-1 \\
32-1 \\
37-1 \\
48-1 \\
50-1 \\
60-1 \\
63-1\end{array}$ \\
\hline 4 & $\begin{array}{l}\text { Chronic HTN + } \\
\text { with PE superimposed }\end{array}$ & 9 & $0-1$ & $\begin{array}{l}4-1 \\
6-1\end{array}$ & $14-1$ & & $\begin{array}{l}27-1 \\
43-1 \\
60-1 \\
97-1 \\
5 \mathrm{M}+17-1 \\
\end{array}$ \\
\hline 5 & Eclampsia & 14 & $\begin{array}{l}0-6 \\
1-2\end{array}$ & $\begin{array}{l}2-3 \\
3-1\end{array}$ & 7-1 & $\begin{array}{l}3 \text { weeks-1 } \\
\text { PPE }\end{array}$ & \\
\hline 6 & $\begin{array}{l}\text { HELLP syndrome } \\
\text { PE with severe } \\
\text { Features- } 6 \\
\text { Eclampsia- } 1\end{array}$ & 7 & $0-6$ & & $8-1$ & & \\
\hline 7 & Total & 77 & 29 & 18 & 9 & 3 & 18 \\
\hline
\end{tabular}




\begin{tabular}{|rrrrrrr|}
8 & 3 & 37.662 & 23.377 & 11.688 & 3.896 & 23.377 \\
\hline
\end{tabular}

The pregnancy continued for a period of less than a week in $37.66 \%$ of cases, for less than two weeks in $23.37 \%$, less than three weeks in $11.68 \%$, less than four weeks in $3.89 \%$ and pregnancy continued for more than four weeks in $23.37 \%$ of patients. The decision to continue the pregnancy on medical therapy or termination of pregnancy by delivery would be keeping in mind the welfare of both the pregnant lady and the fetus

Table 9: Associated conditions and maternal complications in different groups of hypertensive disorders of pregnancy.

\begin{tabular}{|c|c|c|c|c|c|c|c|}
\hline \multicolumn{2}{|c|}{ S. no./diagnosis } & $\begin{array}{l}\text { Severe } \\
\text { anemia }\end{array}$ & $\begin{array}{l}\text { Hypot } \\
\text { hyroid }\end{array}$ & $\begin{array}{l}\text { GDM+ } \\
\text { OVER } \\
\text { T DM }\end{array}$ & $\begin{array}{l}\text { Multiple } \\
\text { gestation }\end{array}$ & Other conditions & $\begin{array}{l}\text { Fetal } \\
\text { growth } \\
\text { restriction }\end{array}$ \\
\hline 1 & $\begin{array}{l}\text { Gestational HTN } \\
N=14\end{array}$ & 1 & 3 & 3 & 2 & $\begin{array}{l}\text { Chronic liver disease } \\
\text { andportal HTN 1; grade } 3 \\
\text { diastolic dysfunction } 1\end{array}$ & \\
\hline 2 & $\begin{array}{l}\text { PE without severe } \\
\text { features } N=6\end{array}$ & $\begin{array}{l}\text { Mod severe } \\
\text { anemia-1 }\end{array}$ & & & & & \\
\hline 3 & $\begin{array}{l}\text { PE with severe } \\
\text { features } N=27 \text {; early } \\
\text { onset preeclampsia- } 4\end{array}$ & & 3 & 1 & 2 & $\begin{array}{l}\text { Rh negative- } 1 \text {, abruption- } \\
1 \text {, oligoamnios- } 6 \text {, } \\
\text { abnormal Doppler blood } \\
\text { flow- } 4 \text {, abnormal Doppler } \\
\text { blood flow- } 4 \text {, ascites- } 2 \text {, } \\
\text { herpes zoster }-1\end{array}$ & 15 \\
\hline 4 & Chronic HTN N=9 & & 2 & 4 & & & \\
\hline 5 & $\begin{array}{l}\text { Eclampsia- } 14, \\
\text { antepartum- } 4, \\
\text { antrapartum- } 3 \text {, } \\
\text { imminent- 5, } \\
\text { postpartum- } 2\end{array}$ & $\begin{array}{l}\text { Severe } \\
\text { anemia }-3,4 \\
\text { units FFP -1, } \\
\text { PC-1 }\end{array}$ & & & 1 & $\begin{array}{l}\text { Multiple pregnancy- } 1 \text {, } \\
\text { abruption, couvelaire } \\
\text { uterus }-1 \text {, retinopathy, } \\
\text { temporary loss of vision - } \\
1 \text {, ascites - } 1\end{array}$ & FGR- 3 \\
\hline 6 & $\begin{array}{l}\text { HELLP syndrome } \\
\mathrm{N}=7 \text {, multiple units } \\
\text { of blood products- } 6 \\
\text { cases }\end{array}$ & 6 & 1 & & & $\begin{array}{l}\text { Abruption- } 3 \text {, } \\
\text { thrombocytopenia- } 1 \text { lakh } \\
\text { and less- } 3 \text {, acute kidney } \\
\text { injury- } 3 \text {, PPH- } 2 \text {, jaundice } \\
\text { in one, acute pancreatitis in } \\
\text { one }\end{array}$ & \\
\hline 7 & Total- 77 & 11 & 9 & 8 & 5 & $\begin{array}{l}\text { Abruption } 5 \text {, AKI } 3 \\
\text { PPH } 3 \text {, acute pancreatitis } 1 \text {, } \\
\text { retinopathy, temporary loss } \\
\text { of vision- } 1 \text {, ascitis- } 3\end{array}$ & 18 \\
\hline 8 & $\%$ & 14.28 & 11.68 & 10.39 & 6.49 & $\begin{array}{l}\text { Abruption- } 6.57 \text {, } \\
\text { thrombocytopenia } 3.94, \\
\text { AKI } 3.94, \text { PPH } 3.94, \\
\text { ascites } 3.94\end{array}$ & 23.37 \\
\hline
\end{tabular}

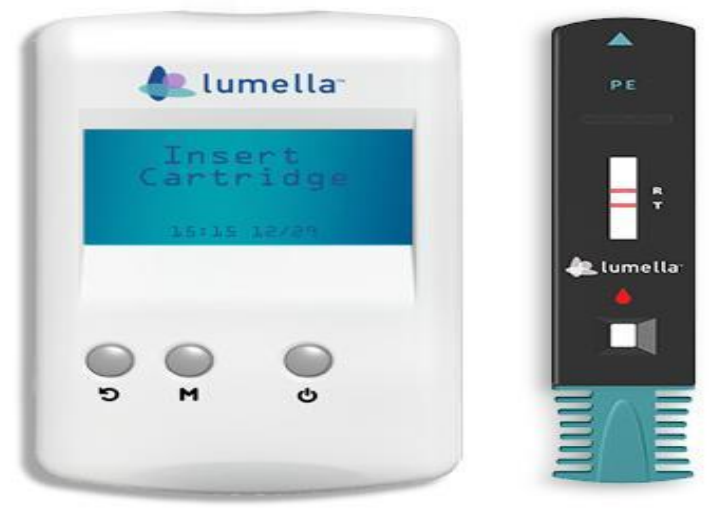

Figure 1: Lumella; source (DiabetOmics, Inc.).
Estimates the concentration of GlyFn; 10 minutes to read from a finger stick sample; source: DiabetOmics Inc., Beaverton, OR97006, USA

\section{DISCUSSION}

In this study the percentage of positivity was found to be highest in eclampsia, $78.57 \%$, next in PE with severe features $74.07 \%$. In descending order the GlyFn positivity was found to be in HELLP syndrome and Gestational HTN, 71.42\%. In PE without severe features, the Glyfn positivity was $66.66 \%$ and in chronic HTN with PE superimposed, a positivity rate of $55.55 \%$. This suggests highest positivity in the most severe forms of $\mathrm{PE}$ and 
lowest positivity in the less severe forms of the spectrum of hypertensive disorders of pregnancy.

GlyFn positivity was investigated as a surrogate marker to diagnose $\mathrm{PE}$ in other studies. If the positivity rates are consistently high, it could serve as a PE diagnostic marker, in addition to HTN and other severe features.

The overall GlyFn positivity was $71.42 \%$ for the six groups included in the study, PE and HDP. We have done the qualitative test and not the quantitative test.

Need more data from large trials. We also had a control group, but because of the high dropout rate, we could not come out with the results. In India, the ANC, antenatal checkup would be from the in-laws place and delivery would be from the mother's place, which accounts for the high drop outs, lost to follow up. Hence had to abort this arm of the study.

As per the ACOG 2019 bulletin, if the proteinuria were less than 2 plus in addition to HTN, they would be included under the group gestational HTN. ${ }^{28}$ In the course of the disease, these cases of gestational HTN may develop other severe features and may be grouped under PE with severe features, eclampsia, and HELLP syndrome.

Though categorized under different groups, they could represent, in the chronology of events, one continuous spectrum of the same underlying pathologic process.

In our previous study, $65.55 \%(\mathrm{~N}=358 / 547)$ of women the diastolic blood pressure was less than $110 \mathrm{~mm}$ of mercury and $51.98 \%(\mathrm{~N}=340 / 654)$ of cases of eclampsia and imminent eclampsia occurred after 34 weeks of gestation (the late onset group). ${ }^{5}$

It is the late onset group of PE, where the fetus would have grown, proper timely management could salvage the fetus and avoid the preventable maternal complications by timely delivery. A greater attention and care paid to this group could considerably reduce maternal mortality.

From these observations it is evident that even in cases when $\mathrm{BP}$ is not in the range of severe PE, the risk of eclampsia exists.

The maternal complications and fetal complications, FGR, NICU admissions, intrauterine fetal death, (IUD), stillbirth, neonatal death were all more common in PE with severe features, eclampsia and HELLP syndrome.

Impending fetal death in utero, imminent eclampsia, eclampsia and HELLP syndrome would mandate immediate intervention and delivery. Labour was induced in $22 / 77$ (28.57\%) of cases. Some would spontaneously set into preterm labour. An elective caesarean would be necessary in some.
Antenatal steroid administration was done when preterm delivery was planned to save the fetus and also to avoid respiratory distress syndrome (RDS) complication. Labetalol and nifidepine were most commonly used drugs to control HTN in the majority of cases in the study. Magnesium sulphate was administered to all cases of eclampsia, imminent eclampsia, also in severe PE in labour.

\section{Placental abruption in PE and HDP}

In this study $(\mathrm{n}=77)$ there was placental abruption in 5 $(6.57 \%)$. In our previous study, placental abruption was observed in 23/662 (3.47\%) of cases of eclampsia and imminent eclampsia. ${ }^{5}$ Abruptio placentae $10 \%$ and $7-10 \%$ reported by others. ${ }^{29,30}$

\section{Adverse maternal complications}

Ninety two percent patients had no complications. There was maternal mortality in 2 subjects, ARF in 2 subjects, $\mathrm{PPH}$ in 2 subjects, DIC in 1 subjects and magnesium toxicity in 4 subjects. Some of these complications were in association with each other in most subjects. ${ }^{31}$

\section{Mode of delivery}

In the study, vaginal delivery was recorded in $32 / 77$ $(41.55 \%)$. A caesarean delivery was necessary in $45 / 77$ $(58.44 \%)$ of HDP cases.

In our previous study, the total number of deliveries was 656 , with vaginal deliveries in $336(66.46 \%)$ patients, caesarean deliveries in $220(33.54 \%)$ patients. ${ }^{5}$ Our caesarean delivery rate of $33.54 \%$ in the very high risk cases of eclampsia and imminent eclampsia is very low compared to others.

$71 \%$ (53) patients delivered vaginally and $29 \%$ patients (22) required caesarean section. 9 deliveries out of 53 vaginal deliveries were spontaneous and 44 vaginal deliveries were induced..$^{31}$

\section{Perinatal outcome}

In perinatal outcome, NICU admissions 34 (44.73\%), IUD 9 (11.84\%), NND $4(5.26 \%)$ and SB 1 (1.31\%). Total perinatal mortality in 14 was $18.18 \%$.

The perinatal mortality was 167/582 (28.69\%), PNM when birth weight was $>1.5 \mathrm{~kg}$ was $59 / 426 \quad(13.84 \%)$, intrauterine fetal deaths at admission were $54(8.5 \%)$, there were four sets of twins. ${ }^{5}$

The period of gestation when eclampsia occurs would be significant because it would have a direct bearing on the perinatal outcome. If a number of eclampsia cases occur at early weeks of gestation and at low fetal weights, the perinatal survival would be affected. 
A birth weight of $2.6 \mathrm{~kg}$ and above was recorded in $25.61 \%$ of the cases of HDP. While a birth weight of $2.5 \mathrm{~kg}$ and below was recorded in $74.39 \%$ of the cases of HDP. It is noteworthy that in HDP $74.39 \%$ of the cases are SGA newborns. Increased GlyFn levels were significantly associated with gestational age at delivery $(\mathrm{p}<0.01)$, blood pressure $\left(\mathrm{P}^{1 / 4}=04\right)$, and small-for gestational-age neonates. ${ }^{17}$

Patients in the clinical PE group were more likely to give birth earlier $(\mathrm{p}<0.01)$ and have lower neonatal birthweights. ${ }^{17}$

Overall biomarker performance was not different between early-versus late onset $\mathrm{PE}$, or between non-severe and severe PE. ${ }^{25}$ A significant proportion of subjects clinically stratified as GH were positive for PE biomarkers and also exhibited a higher frequency of preterm birth than control patients. ${ }^{25}$

\section{Limitations}

Our study included a total of 77 women with HDP. Hence in each group of severe and less severe disease of PE and HDP, the numbers being small, there is a restraint on statistical analysis. Need to validate the observations in a larger population of women with HDP.

The control arm of the study could not be continued as planned, due to certain reasons.

\section{CONCLUSION}

GlyFn positivity was found to be highest in the severe forms of PE and eclampsia. The positivity declined in the less severe disease. The birth weight in the severe forms of PE group was significantly lower $(p<0.0006)$ than in the less severe disease. The differences in the birth weight among the GlyFn positive and normal groups was not significant for this population size $(\mathrm{p}=0.38)$.

We conclude that GlyFn could serve as a surrogate marker to identify the severe PE with adverse maternal and fetal outcomes.

\section{ACKNOWLEDGMENTS}

Authors would like to thank the medical director and superintendent of MGMH/OMC, Hyderabad for the permission accorded to conduct the study. They would like to convey heartfelt thanks and appreciation to Diabetomics, for the supply of test kits Lumella to test GlyFn in MGMH, supporting the research study. They also thank Ms. Sayeeda Banu for training the doctors in performing the test, and Mr. Raghavan Veeravalli, for ensuring the supply of test kits.
Funding: No funding sources

Conflict of interest: None declared

Ethical approval: The study was approved by the Institutional Ethics Committee

\section{REFERENCES}

1. Hladunewich M, Karumanchi SA, Lafayette R. Pathophysiology of the clinical manifestations of preeclampsia. Clin J Am Soc Nephrol. 2007;2(3):5439.

2. Khan KS, Wojdyla D, Say L, Gülmezoglu AM, Van Look PF. WHO analysis of causes of maternal death: a systematic review. Lancet. 2006;367(9516):106674.

3. Steegers EA, von Dadelszen P, Duvekot JJ, Pijnenborg R. Pre-eclampsia. Lancet. 2010;376(9741):631-44.

4. Nobis PN, Hajong A. Eclampsia in India Through the Decades. J Obstet Gynaecol India. 2016;66(1):172-6.

5. Pratibha D, Reddy AM, Malati P, Bhavana K, Shobha R, Harita R. Management of Eclampsia and Imminent Eclampsia, Maternal and Perinatal Outcome in 666 Cases-2003-2007 at Government Maternity Hospital in Hyderabad. Open J Obstet Gynecol. 2017;7:193-207.

6. Report of the National High Blood Pressure Education Program Working Group on High Blood Pressure in Pregnancy. Am J Obstet Gynecol. 2000;183(1):1-22.

7. Homer CS, Brown MA, Mangos G, Davis GK. Nonproteinuric pre-eclampsia: a novel risk indicator in women with gestational hypertension. J Hypertens. 2008;26(2):295-302.

8. Pettit F, Brown MA. The management of preeclampsia: what we think we know. Eur J Obstet Gynecol Reprod Biol. 2012;160(1):6-12.

9. Sibai BM, Stella CL. Diagnosis and management of atypical preeclampsia-eclampsia. Am J Obstet Gynecol. 2009;200(5):481.

10. Magee LA, von Dadelszen P, Bohun CM, Rey E, ElZibdeh M, Stalker S, et al. Serious perinatal complications of non-proteinuric hypertension: an international, multicentre, retrospective cohort study. J Obstet Gynaecol Can. 2003;25(5):372-82.

11. Levine RJ, Maynard SE, Qian C, Lim KH, England LJ, Yu KF, Schisterman EF, Thadhani R, Sachs BP, Epstein FH, Sibai BM, Sukhatme VP, Karumanchi SA. Circulating angiogenic factors and the risk of preeclampsia. N Engl J Med. 2004;350(7):672-83.

12. Macintire K, Tuohey L, Ye L, Palmer K, Gantier M, Tong S, Kaitu'u-Lino TJ. PAPPA2 is increased in severe early onset pre-eclampsia and upregulated with hypoxia. Reprod Fertil Dev. 2014;26(2):351-7.

13. Santillan MK, Santillan DA, Scroggins SM, Min JY, Sandgren JA, Pearson NA, et al. Vasopressin in preeclampsia: a novel very early human pregnancy biomarker and clinically relevant mouse model. Hypertension. 2014;64(4):852-9.

14. Yeung EH, Liu A, Mills JL, Zhang C, Männistö T, Lu Z, Tsai MY, Mendola P. Increased levels of copeptin 
before clinical diagnosis of preeclampsia. Hypertension. 2014;64(6):1362-7.

15. Rasanen JP, Snyder CK, Rao PV, Mihalache R, Heinonen S, Gravett MG, et al. Glycosylated fibronectin as a first-trimester biomarker for prediction of gestational diabetes. Obstet Gynecol. 2013;122(3):586-94.

16. Rasanen J, Girsen A, Lu X, Lapidus JA, Standley M, Reddy A, et al. Comprehensive maternal serum proteomic profiles of preclinical and clinical preeclampsia. J Proteome Res. 2010;9(8):4274-81.

17. Rasanen J, Quinn MJ, Laurie A, Bean E, Roberts CT, Nagalla SR, Gravett MG. Maternal serum glycosylated fibronectin as a point-of-care biomarker for assessment of preeclampsia. Am J Obstet Gynecol. 2015;212(1):82.

18. Huhn EA, Hoffmann I, Martinez De Tejada B, Lange S, Sage KM, Roberts CT, Gravett MG, Nagalla SR, Lapaire O. Maternal serum glycosylated fibronectin as a short-term predictor of preeclampsia: a prospective cohort study. BMC Pregnancy Childbirth. 2020;20(1):128.

19. Monte S. Biochemical markers for prediction of preclampsia: review of the literature. J Prenat Med. 2011;5(3):69-77.

20. Staff AC, Benton SJ, von Dadelszen P, Roberts JM, Taylor RN, Powers RW, Charnock-Jones DS, Redman CW. Redefining preeclampsia using placenta-derived biomarkers. Hypertension. 2013;61(5):932-42.

21. Poon LC, Nicolaides KH. First-trimester maternal factors and biomarker screening for preeclampsia. Prenat Diagn. 2014;34(7):618-27.

22. Kar M. Role of biomarkers in early detection of preeclampsia. J Clin Diagn Res. 2014;8(4):1-4.

23. Wu P, van den Berg C, Alfirevic Z, O'Brien S, Röthlisberger M, Baker PN, Kenny LC, Kublickiene K, Duvekot JJ. Early Pregnancy Biomarkers in PreEclampsia: A Systematic Review and Meta-Analysis. Int J Mol Sci. 2015;16(9):23035-56.
24. Shruthi K, Pranathi R, Gayathri V, Prathyusha R, Bhargavi R. Glycosylated Fibronectin Point of care Test for Triage and Surveillance of Hypertension in Pregnancy Cases: A Retrospective Observational Case Control Study. J Obstet Gynecol India. 2021.

25. Nagalla SR, Janaki V, Vijayalakshmi AR, Chayadevi K, Pratibha D, Rao PV, Sage KM, Nair-Schaef D, Bean E, Roberts CT Jr, Gravett MG. Glycosylated fibronectin point-of-care test for diagnosis of preeclampsia in a low-resource setting: a prospective Southeast Asian population study. BJOG. 2020;127(13):1687-94.

26. Powers RW, Catov JM, Bodnar LM, Gallaher MJ, Lain KY, Roberts JM. Evidence of endothelial dysfunction in preeclampsia and risk of adverse pregnancy outcome. Reprod Sci. 2008;15(4):374-81.

27. Stubbs TM, Lazarchick J, Horger EO. Plasma fibronectin levels in preeclampsia: a possible biochemical marker for vascular endothelial damage. Am J Obstet Gynecol. 1984;150(7):885-7.

28. ACOG Practice Bulletin No. 202: Gestational Hypertension and Preeclampsia. Obstet Gynecol. 2019;133(1):1.

29. Mattar F, Sibai BM. Eclampsia. VIII. Risk factors for maternal morbidity. Am J Obstet Gynecol. 2000;182(2):307-12.

30. Sibai BM. Diagnosis, prevention, and management of eclampsia. Obstet Gynecol. 2005;105(2):402-10.

31. Kanani B, Garala NJ. A clinical observational study in cases of eclampsia. Int $\mathbf{J}$ Reprod Contracept Obstet Gynecol. 2019;8:3524-7.

Cite this article as: Devabhaktuni $\mathrm{P}$, Ponnuru $\mathrm{M}$, Devang CL, Rao PV. Glycosylated fibronectin positivity in the spectrum of hypertensive disorders of pregnancy in relation to the severity and adverse outcomes. Int J Reprod Contracept Obstet Gynecol 2022; 11:892-903. 